\title{
SEMIOTIC ANALYSIS OF "EURO 2020" TOURNAMENT'S MEMES ON SOCIAL MEDIA TWITTER
}

\author{
Irfan Fauzan ${ }^{1}$, Tiarma Ika Yuliana ${ }^{2}$, Rr. Astri Indriana Octavita ${ }^{3}$ \\ ${ }^{1,2,3}$ Universitas Indraprasta PGRI, \\ Jl. Nangka Raya No.58 C Tanjung Barat, Jakarta Selatan 12530 \\ Corresponding Author(S): tiarmaika@gmail.com
}

\begin{abstract}
:
The objectives of this research are to find out the signifier /signified and the meaning of Euro 2020 tournament memes. The method of this research is descriptive qualitative. This method was started from collecting, analyzing, and interpreting the data. The data of this research were taken from Twitter platform which published in June-July 2020. The writers used Roland Barthes' theory to analyze the data. The memes divided into the Signifier and Signified that could be verbal text and the visual. The writers also described the denotative and connotative meaning of Euro 2020 memes.st. In this research, the writers found three memes which contained about troll and comedy of Euro 2020 tournament.
\end{abstract}

Keywords: Meme, Semiotic, Euro 2020

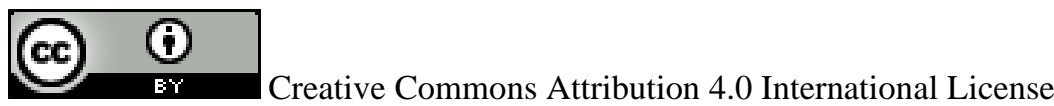

\section{INTRODUCTION}

The development of information technology has made it easier for society to find and obtain information using electronic devices, such as computers or mobile phones. However, from the development of this technology, there is an impact. The impact of the development of information and communication technology has formed a digital era. Information and messages are increasingly accessible because they are available online. Internet technology has led to the emergence of social media that makes it easier for audiences to interact. Social media is a medium that is used to socialize with each other and is done online that allows humans to interact with each other without being limited by space and time, such as Facebook, Twitter, Instagram, and other social media. While social media is a platform for communication, memes are a way of expressing a culturally relevant idea.

Historical meme is basically a meme that uses historical event as a joke (Dewanto \& Cahyono, 2021). To understand the historical meme, people need an acknowledgement of the event that its maker wants to deliver. The meme commonly has at least one hint of a historical event. It can be setting of the event, characters that appear in the event and so on. Memes have become popular because they can be used as material jokes, satire, 
expressions of users' feelings in cyberspace. And this quickly became popular and endemic (Juditha, 2015).

A meme is an image or video that represents the thoughts and feelings of a specific audience. Meme is also a phenomenon of the Internet culture and a cherished communication artifact of our times (Denisova, 2019). Memes have become such a popular phenomenon in recent years. Its popularity can be seen from the many memes that we find spread on the internet and social media in particular. She said that Biologist Richard Dawkins is the pioneer of meme studies. His seminal book The Selfish Gene, published in 1976, first mentioned memes as a cultural analog to a gene. Dawkins (Holm, 2021) argued that memes resemble genes in their structure, mechanisms of distribution and survival, productivity, and fecundity. A gene is a molecular unit of people's bodies, a biological code holding important information for building and maintaining cells and passing the invaluable hereditary data to offspring.

In its development, memes are more familiar with image illustrations and have become a term attached to creatively processed images. Usually, memes use a collection of photos of public figures and celebrities and the creators just need to complete the photo of their findings with text, or by reducing and adding image elements through a simple digital processing process, depending on the appropriateness of the context of the information to be conveyed. After the creation process is complete, the photo meme or image will be distributed and spread through share, retweets, or repost services on social media. The popularity of memes slowly began to spread, became widely known, and began to be used for various purposes, where memes were formed into conventional and more varied humor. The function of memes develops into parody-style illustrations where memes usually imitate the intended object with a slapped style. Memes are also often processed in a satirical style and tend to be sharp. In addition, memes can also be used as a means of spreading criticism from their creators on a problem that occurs in society. Not many of the memes that are spread on the internet and social media are a form of expressing opinions. Not infrequently memes appear in response to sensitive issues that are in the public spotlight. These memes appear with various topics in response to news, issues, events, or even personal experiences.

A meme is an idea, behavior, or style that spreads from person to person within a culture. A meme acts as a unit for carrying cultural ideas, symbols, or other practices that can be transmitted from one thought to another through writing, speech, gestures, rituals, or replicable phenomena with an imitated theme. The writers use semiotic approach to interpret the signs in meme. Each memes consists of sign (qualisign), object (icon) and interpretant (rheme) which stand for a meaning or idea conveyed by the meme users (Muliadi, 2015).

Semiotics is one of the sciences or analytical methods to study signs. As a species, we seem to be driven by a desire to make meanings: above all, we are surely Homo significant - meaning-makers. We cannot avoid interpreting things, and, in doing so, we treat them as 'signs'. Signs take the form of words, images, sounds, odors, flavors, actions, events, objects, and so on, but these have no intrinsic meaning and become signs only when we invest them with meaning (Sena et al., 2016). Semiotics is the study of signs, the functioning of signs, and the production of meaning. Semiotics views communication as 
a process of giving meaning through signs, namely how signs represent objects, ideas, things, and so on that are outside the individual. Semiotics is used in topics such as messages, media, culture, and society. (Isnaniah \& Tiya Agustina, 2020). A sign is something that consists of something else or adds a different dimension to something, by using everything that can be used to mean something else. Verbal and nonverbal messages are a form of sign. Semiotics wants to study how humans interpret the things found in nature. Meaning in this case cannot be confused with communicating. Semiotics examines how various elements interact with human knowledge to produce meaning. Semiotics studies is the way how to understand the sign system in memes which play a role in guiding readers to be able to capture the message contained in it.

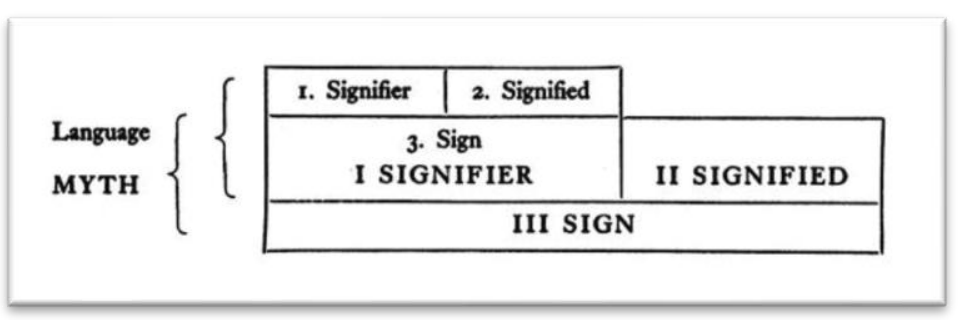

Figure 1 Barthes' map

Source: Barthes, Roland. 1991. Mythologies. New York: The Noonday Press, in Widiastuti, Ismail and Iswanto, 2020

Barthes' map shows how the denotative sign (3) consists of a signifier (1) and a sign (2). At the same time, the denotative sign is also connotative (4). Denotation is the first level whose meaning is closed, socially agreed upon, whose reference is to reality. Denotation is understood as the true meaning; even sometimes it is also confused with references or references. The connotative sign, on the other hand, is open to the possibility of new interpretations. The marker has an openness of meaning or what is called implicit, indirectly, and uncertainly (Widiastuti, Ismail, and Iswanto, 2020). With Roland Barthes Semiotics Analysis, the author wants to analyze several memes that discuss the conditions and events that occurred during the Euro 2020 Tournament.

Euro 2020, the 16th edition of the flagship UEFA competition, is being styled as a celebration, with games being held across Europe to mark the 60th anniversary of the first-ever tournament (though it will strictly be 61 years). Euro 2020 features 24 teams 20 from automatic qualification and the remaining four decided through the play-offs. The format for the final tournament is the same as Euro 2016, making for six groups comprised of four teams. Even though UEFA pushed back the tournament a year due to the complications of the Covid-19 pandemic, it will still be called Euro 2020 and not Euro 2021. The decision to keep the name stems from the fact that most marketing and promotional materials were already branded with 'Euro 2020' and they are unwilling for it to go to waste. UEFA confirmed their decision to keep Euro 2020 as the name of the tournament in April 2020, going on to add that the original name is a symbol of how the football world stuck together amidst the difficulties of dealing with the effects of the coronavirus (goal.com).

\section{METHOD}

This study uses a qualitative method, According to Sugiyono (2017), the research method is a scientific way to obtain data with certain goals and uses. Based on this, four keywords need to be considered, namely scientific method, data, purpose, and usability. Therefore, 
the researchers chose to use qualitative research methods to determine how to find, collect, process and analyze the data from the research. The research is used descriptive qualitative research. Descriptive qualitative research is in the form of research with a case study method or approach (Sugiyono, 2017). In qualitative research, an instrument is a person or human instrument, namely the researchers themselves. To be able to become an instrument, the researchers must have the provision of theory and broad insight, to be able to ask questions, analyze, photograph, and construct the social situation understudy to be clearer and more meaningful.

The field of study of semiotics or semiology is studying the function of signs in the text, namely, how to understand the sign system in the text which plays a role in guiding the reader, to be able to capture the message contained in it. In other words, semiology plays a role in interrogating the codes installed by the author so that readers can enter the chambers of meaning stored in a text. A reader is like a treasure hunter with a map, he must understand the code and the signs that show where the meanings are stored, and then with the guidance of the punctuation marks the door of meaning will open (Katamba, 2020). The data is taken from the social media Twitter platform. The memes contained about Euro 2020 which are published from June 2021 until July 2021. The writers began by collecting memes on social media Twitter related to EURO 2020 then classified them into four categories (Signifier, Signified, Denotation and Connotation). The next step explain the signs, objects, and the meaning or interpretation of the symbols displayed in memes.

\section{RESULTS AND DISCUSSION}

From the results of data analysis, there are many interesting things contained in memes that represent during the Euro 2020 Tournament. Most memes contain about troll and comedy of Euro 2020 Tournament.

Meme 1:

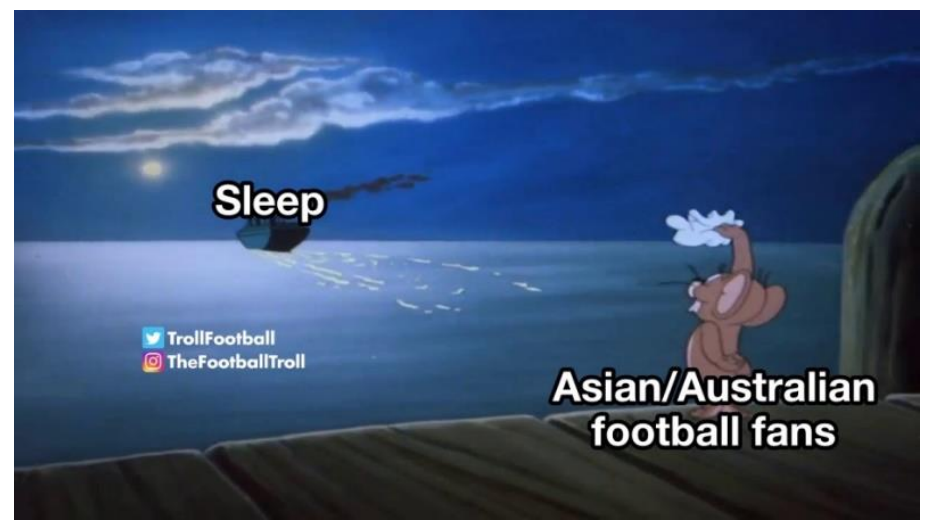

Figure 1 First Meme: Scenes from Tom and Jerry Cartoon Source: https://twitter.com/TrollFootball/status/1403285687986651141

Table 1 Scenes from Tom and Jerry Cartoon

\begin{tabular}{lll}
\hline \multicolumn{1}{c}{ SIGNIFIER } & \multicolumn{1}{c}{ SIGNIFIED } \\
\hline 1. Jerry & 1. & Fictional Character from Tom and \\
2. Sheep & & Jerry. \\
3. Sleep & 2. & Sea Transportation. \\
4. Asian/Australian Football & 3. & Activity to do when you are tired. \\
Fans & 4. & $\begin{array}{l}\text { People from Asia/Australia who } \\
\text { like to watch Football Match. }\end{array}$ \\
\hline
\end{tabular}


This meme is showing some cartoon scenes from Tom and Jerry Cartoon, produced by Hanna-Barbera Cartoons in 1950, when Jerry is waving goodbye by holding a tissue to the sailing sheep, resulting from helping his new friend "Lion" to escape from the circus and going back home to Africa. On the sheep was written "Sleep" word, while on Jerry's side written "Asian/Australian Football Fans". Denotatively, the writers saw that Jerry was waving goodbye by holding a tissue to the sailing sheep, which results from helping his new friend "Lion" to escape from the circus and going back home to Africa. Eventually, it makes him sad. The connotation meaning is the Euro 2020 match was played in the Afternoon in Europe, while in Asia and Australia it was played in the Evening/Noon, which results in a different time zone. Because of that, Asian and Australian Football fans who want to see Euro 2020 match cannot have a normal sleep because, in their region, it was played in the Evening/Noon. This could be dangerous because if someone lacks sleep, they could easily sick, and probably it will make them sad.

Meme 2:

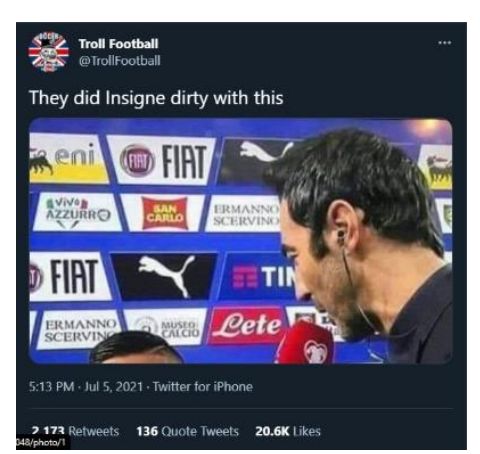

Figure 2 Second Meme

Source: https://twitter.com/TrollFootball/status/1411991701397250048

Table 2 The Post-Match Interview in Euro 2020 Tournament

\begin{tabular}{lll}
\hline \multicolumn{1}{c}{ SIGNIFIER } & \multicolumn{1}{c}{ SIGNIFIED } \\
\hline $\begin{array}{l}\text { 1. They did Insigne dirty with this } \\
\begin{array}{l}\text { 2. Lorenzo Insigne } \\
\text { 3. Reporter }\end{array}\end{array}$ & 1. & $\begin{array}{l}\text { Caption, means some harsh and unfair } \\
\text { thing that happened to someone. }\end{array}$ \\
& $\begin{array}{l}\text { 2. } \\
\text { 3. }\end{array}$ & $\begin{array}{l}\text { An Italian Professional Football Player } \\
\text { Person who reports news/something, } \\
\text { sometimes also asking a question. }\end{array}$ \\
\hline
\end{tabular}

The second meme is about the Post-Match Interview in Euro 2020 Tournament, showing a reporter who talked to a player but only his hair was shown, later the player known as Lorenzo Insigne, an Italian Professional Football Player, results from the caption above "They did Insigne dirty with this". The interpretation in denotation is about Post-Match Interview between a Reporter and Italian Footballer Lorenzo Insigne, but only his hair was shown to the camera. The connotation meaning is Lorenzo Insigne is an Italian Footballer who has $163 \mathrm{~cm}$ tall, according to Transfermarkt.com. Because of his height, he is considered a short footballer. When doing the post-match interview, the cameramen were probably confused about whether he had to shoot Insigne or The Reporter who has a quite different height between them, and he eventually decided to shoot Reporter, which means Insigne cannot have a full shoot body. 
Meme 3:

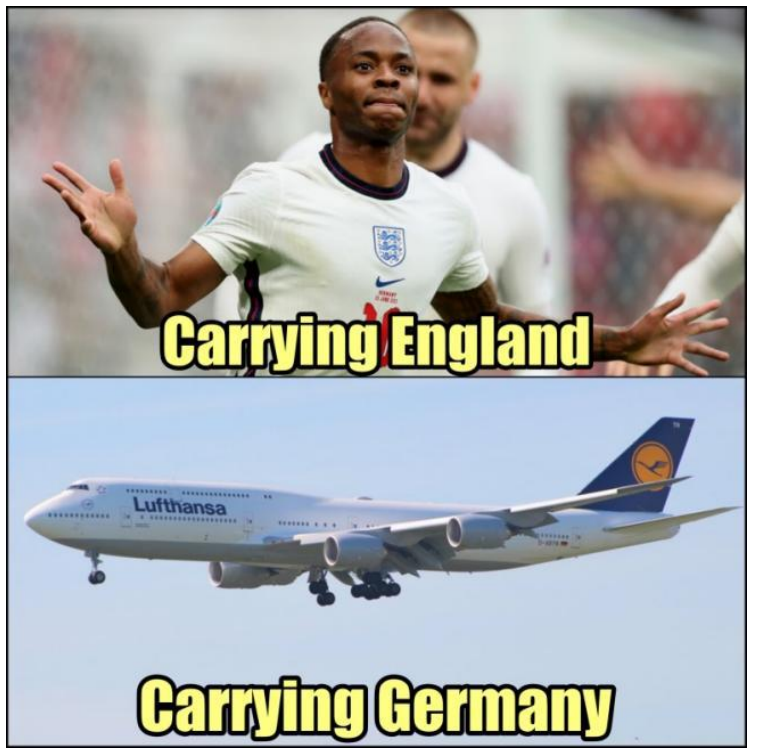

Figure 3 Third Meme

Source: https://twitter.com/TrollFootball/status/1409936461013557249

Table 3 Raheem Sterling

\begin{tabular}{ll}
\hline \multicolumn{1}{c}{ SIGNIFIER } & \multicolumn{1}{c}{ SIGNIFIED } \\
\hline 1. Raheem Sterling & 1. Professional English Footballer \\
2. Airplane & 2. Transportation which can fly in the air. \\
3. Carrying England & 3. Caption means carried England to \\
4. Carrying Germany & something (win) \\
& 4. Caption means carried England to \\
& something (lose) \\
\hline
\end{tabular}

The third meme is about the picture of English Footballer Raheem Sterling doing a celebration containing the caption "Carrying England" inside it, and the picture of an Airplane captioned "Carrying Germany" inside it. The denotation meaning is English footballer Raheem Sterling doing a celebration after scoring in the Football Match, and the picture of Airplane flying in the air. The connotation meaning is the meme is explaining about Knockout Stage Match in Euro 2020 when England faced Germany at Wembley Stadium. England won 2-0 thanks to Raheem Sterling and Harry Kane's goal. The results cause England to go to the Quarter-Final stage and since Raheem Sterling scored a goal, he was captioned "Carrying England" which means England National Football Team. While Germany loses, they cannot qualify for the next round and ended up being carried by Airplane to go back to Germany.

According to Deacon and Kull (Cannizzaro, 2016) developments in semiotics suggest that memes should be considered as, an observation which in turn suggests that it would be useful to think of internet memes as sign systems.

\section{CONCLUSION}

The existence of this meme describes unique events and facts that occurred in the Euro 2020 Tournament. The denotative and connotative meanings formed from the signifier and signified are found in each image of the Euro 2020 meme. A signifier that supports 
knowing the signified of an object. There are many markers on each image in the meme. Such as means of transportation, cartoon characters, and a reporter. Most of the meaning of the Euro 2020 meme connotation focuses on the events after the football match. This gives rise to the connotation of the Euro 2020 meme which shows bad behavior or the football ability of a team that is not good as well. Another connotation that leads to aspects of life such as sacrificing sleep at normal times to watch the Euro 2020 match.

\section{REFERENCE}

Denisova, A. (2019). Internet memes and society social, curtural, and political context. New York: Routledge.

Cannizzaro, S. (2016). Internet memes as internet signs: A semiotic view of digital culture. Sign Systems Studies, 44(4), 562-586. https://doi.org/10.12697/SSS.2016.44.4.05

Dewanto, F. B. B., \& Cahyono, S. P. (2021). Semiotics analysis on historical memes in Eno Bening' s Tweet Replies. Allure Journal: A Journal of Applied Linguistics, Linguistics, and Literature, 1(1), 33-52.

Holm, C. H. (2021). What do you meme? The Sociolinguistic potential of internet memes. Interdisciplinary Journal in English, 7, 1-20.

Isnaniah, S., \& Agustina, T. (2020). "Covid-19” Meme in social media: Study of Roland Barthes semiology. BAHTERA : Jurnal Pendidikan Bahasa Dan Sastra, 19(2), 351-378. https://doi.org/10.21009/bahtera.192.010

Juditha, C. (2015). Meme di media sosial: Analisis semiotik meme Haji Lulung. Pekommas, 18(2), 105-116.

Katamba, F. (2020). Should English be spelt as she is spoke? In English Words. https://doi.org/10.4324/9780203205280-16

Muliadi, D. (2015). Universitas Sumatera Utara 7 (Issue 150705005).

Sena, I. P. A, Netra, I. M., \& Mulyawan, I. W. (2016). The analysis of verbal and visual sign of adidas advertisement. Humanis, 17(1), 104-111. 